\title{
Meningioangiomatosis: clinical-radiological features and surgical outcome
}

\author{
A. Arcos; R. Serramito; J.M. Santín; A. Prieto; M. Gelabert; X. Rodriguez-Osorio** and R. Reyes** \\ Departments of Neurosurgery, Neurology* and Pathological Anatomy**. University of Santiago de Compostela. Spain.
}

\section{Summary}

Meningioangiomatosis (MA) is a rare, benign neoplastic disorder involving the cortex and leptomeninges, the sporadic form, commonly presents as refractory localization-related epilepsy, but could be asymptomatic especially in older patients. The imaging features may be entirely non-specific. Magnetic Resonance Imaging (MRI) erroneously suggests meningioma, lowgrade tumour or vascular malformations.

The pathological findings are characterised by proliferation of meningothelial cells and leptomeningeal vessels and calcifications within the mass. Macroscopically there is dense thickening in the underlying cortex, often in a sharply defined area.

In this article we report 3 cases of $M A$, neither of whom had a familiary history or stigmata of Neurofibromatosis (NF). We discuss and place particular emphasis on the clinical presentation and diagnosis imaging, as well as on the outcome. We also review the literature concerning about the aetiology, pathology findings and imaging features of MA.

KEY WORDS: Brain tumor. Histopathology. Meningioangiomatosis. Magnetic resonance imaging. Seizure.

Meningioangiomatosis: características clínico-radiológicas y resultados quirúrgicos

\section{Resumen}

La meningioangiomatosis (MA) es un proceso neoplásico benigno raro, que envuelve el córtex y leptomeninges, en su forma esporádica comúnmente se presenta con epilepsia refractaria, en relación a su localización, pero puede ser asintomática, especialmente en adultos mayores. Las características de imagen pueden ser totalmente inespecíficas. Las imágenes de resonancia magnética erróneamente sugieren la presencia de un

Recibido: 25-01-10. Aceptado: 8-04-10 meningioma, tumores de bajo grado, o malformaciones vasculares.

Los hallazgos patológicos se caracterizan por la proliferación de células meningoteliales, vasos leptomeningeos y calcificaciones dentro del tumor. Macroscópicamente se observa un denso engrosamiento en el córtex adyacente, generalmente con un área claramente definida.

En este articulo, se describen 3 casos de MA, ninguno de ellos presentaba historia familiar o estigmas de neurofibromatosis (NF). Nosotros realizamos la discusión, haciendo particular énfasis en la presentación clínica y diagnóstico por imágenes, así como en el pronóstico.

PALABRAS CLAVE: Tumor cerebral. Histopatología. Meningioangiomatosis. Resonancia magnética. Convulsiones.

\section{Introduction}

Meningioangiomatosis (MA) was first described by Bassoe and Nuzum in 1915 as an incidental autopsy finding in a 15 -year-old boy with NF2 ${ }^{1}$. Subsequently Worster-Drought et al. ${ }^{31}$ described a similar case en 1937, and named it meningioangiomatossis.

There various aetiological and histogenetic theories of MA as mentioned by Takeshima et al. ${ }^{26} \mathrm{MA}$ was regarded as a maldevelopmental, hamartomatous, reactive or neoplasic lesion originating from meningothelial, fibroblastic, myofibroblastic, smooth muscle or pluripotent cells.

The lesion may be broadly classified into predominantly cellular or predominantly vascular, but the appearances vary depending upon the age of the lesion ${ }^{13}$.

The pathologic criteria for MA may be summarized as follows: leptomenigeal proliferations of nodules, whorls, or bands of meningothelial cells en association with shar-

Abreviations. CT: computerised tomography. EEG: Electroencephalography. MA: meningioangiomatosis. MRI: magnetic resonance imaging. NF: Neurofibromatosis. 


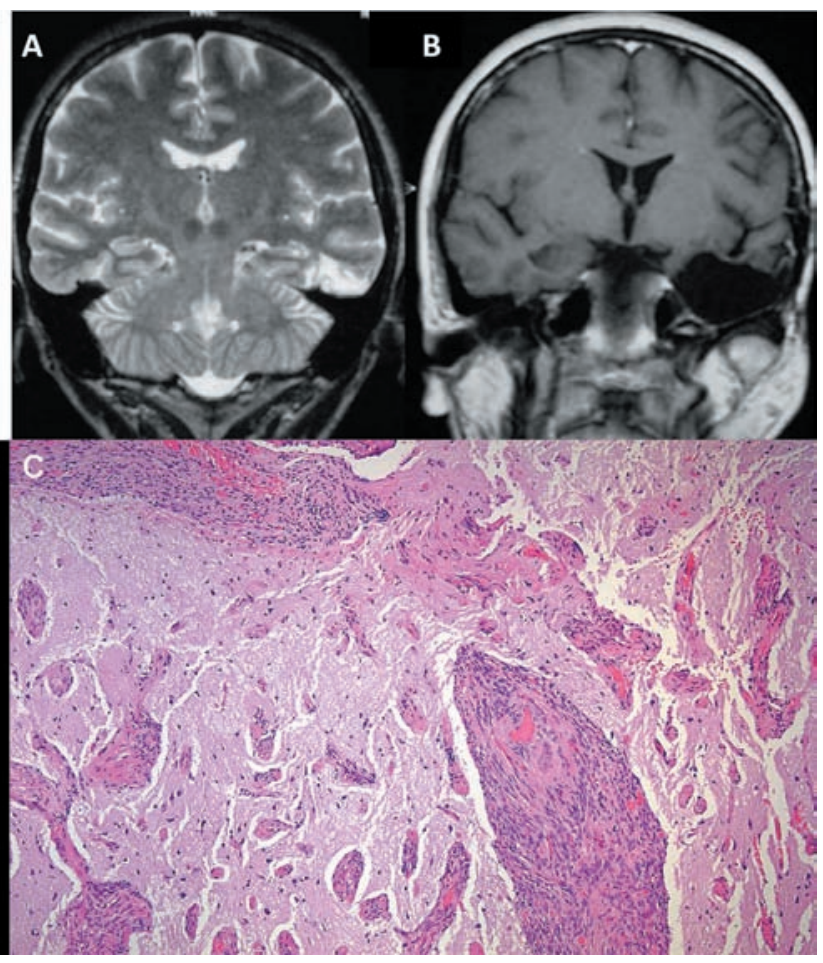

Figure 1. (A) T2-weighted MR images on coronal slice revealed irregular yuxtacortical high intensity in left temporal lobe that involved temporal inferior and fusiform gyrus. (B) Postsurgical T1-weighted MR images confirmed complete removal of the temporal inferior and fusiform gyrus. (C) Lesion inside the cerebral cortex, consisting in fibroblast-like cells surrounding blood vessels.

ply demarcated intracortical plaques of proliferating small vessels and perivascular cuffs of spindle-shaped fibroblastlike cells.

\section{Case reports}

Case 1. A 45-years-old woman had history of complex partial seizures, and occasionally secondary generalized seizures from age of 16 . The frequency of seizures was 10 per month. On T1 and T2-weigthed Magnetic Resonance Imaging (MRI) revealed low and high intensity respectively, irregular yuxtacortical left temporal lobe that involved temporal inferior and fusiform gyrus. No significant mass effect was demonstrated. Electroencephalography (EEG) recorded epileptiform discharge in left temporal lobe.

The patient underwent a left temporal craniotomy, and complete removal of the temporal inferior and fusiform gyrus was performed. The tumour was well demarcated, firm and whitish. There was no involvement of the overlying dura.

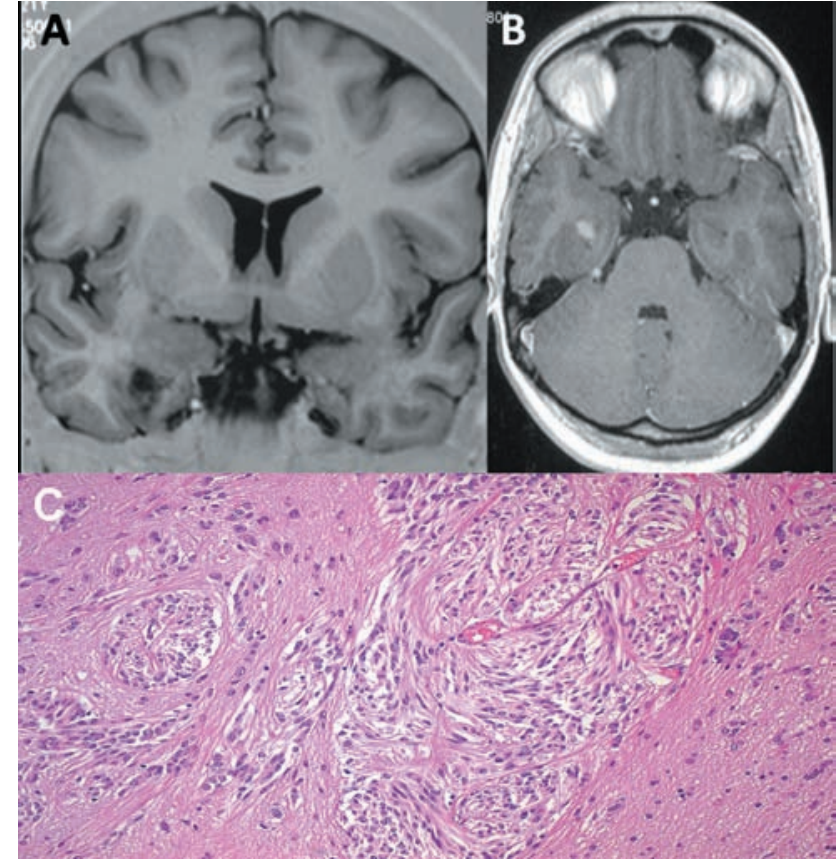

Figure 2. (A) T2-weigted MR isointense left temporal, non-mass-producing lesion extending into insular cortex not well demarcated with the surrounding tissues. Higher signal areas occur in the insula, adjacent external/extreme capsule and adjacent superior temporal gyrus white matter. (B) T1-weighted axial MR 2 years after biopsy revealed a nodule in the deep of the sylvian fissure that had intense enhanced with contrast. (C) Pathologic analysis with haematoxylin and eosin revealed proliferating small vessels and perivascular cuffs of spindle-shaped fibroblastlike cells.

Pathologic examination of the rejected specimen showed a firm, whitish tissue with plate shape on the cortex. Microscopically cortical neurons were entrapped within the lesion and neurofibrillary tangles were identified. Immunohistochemistry showed positivity only for vimentin.

The patient a week after surgery in the same day suffered 6 tonic-clonic seizures. We added new antiepileptic treatment, and two months after we began to reduce the medication. Then she had been free of seizures, but she still continued with medication.

Case 2. A 2-year-old and 10 months girl had 1-year history of generalized seizures. Her psychomotor development was appropriate. MRI showed a left temporal lesion that was nearly isointense with parenchyma, and presented homogeneous enhancement with contrast. The size of the mass was less than $2 \mathrm{~cm}$, not well demarcated with the surrounding tissues with moderate perilesional edema. EEG revealed an asymmetric patron with spike and wave discharges in left temporal lobe. We performed open 


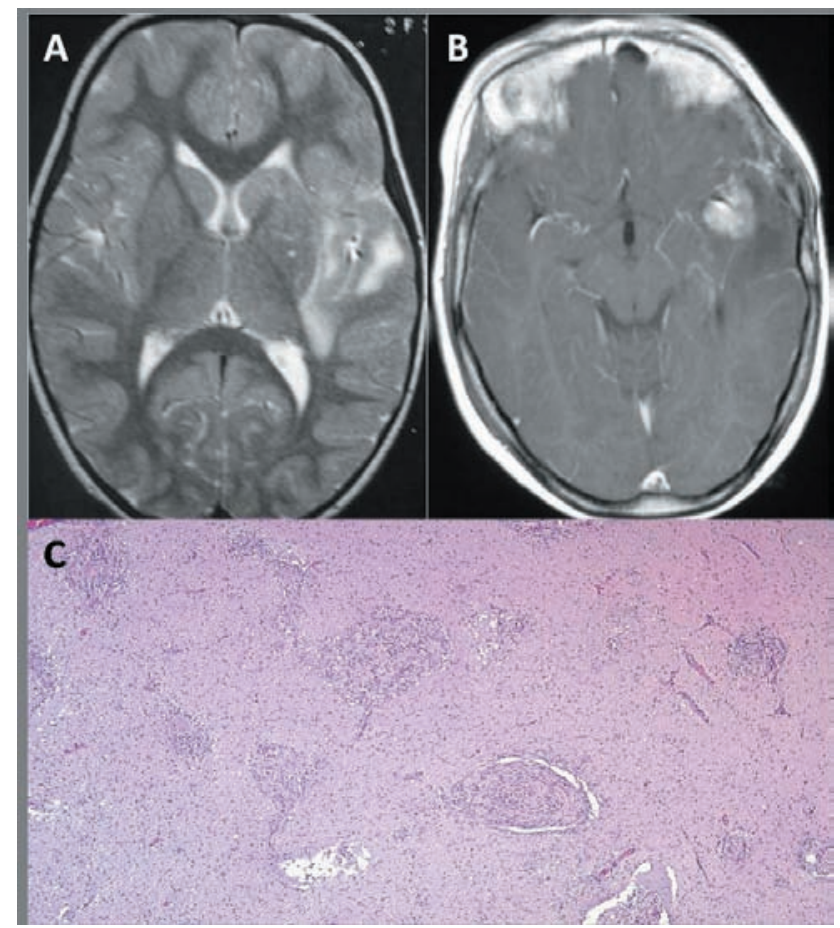

Figure 3. (A) T1-weighted MR images on coronal slice and (B) enhanced T2-weighted sequence shows right mesial temporal gyriform enhancement, without mass effect, with a little cyst inside the lesion and underlying contrastenhanced nodule. (C) Fibroblast-like cells proliferation around the vessels.

biopsy of the lesion. The result was reported as compatible with meningioangiomatosis. The patient continues presented seizure but less than before biopsy (1 per month).

The MRI performed 2 years after revealed an increase in the size of the lesion in comparation with others controls performed before. MRI demostrated isointense signal in on T1-weighted and hiperintensity on T2-weighted sequence, showing a nodule in the deep of the sylvian fissure that had intense enhanced with contrast.

The patient underwent left fronto-temporal craniotomy, when we opened the dura we saw the parenchyma was adhered to it. We appreciated a tough fibrous tissue, located around the sylvian fissure encompassing inferior sylvian artery, and extending into the apex of the insula. Anterior temporal lobectomy and subtotally removed of the tumour was performed.

Pathologic examination revealed fragment of cerebral tissue surrounding of a meningeal thickening. Microscopically, the lesions consisted of extensive fibroblastic proliferation and increase number of vessels surrounded by meningothelial cells. Immunohistochemistry showed positivity only for vimentin.

The patient is asymptomatic since the last surgery had
2010; 21: 461-466

around one seizure/6 months, but still need antiepileptics drugs.

Case 3. A 21-year-old woman had history of complex partial seizures with about 2 attacks per day. MRI showed isointense signal in right medial temporal lobe on T1-weighted and hiperintensity on T2-weighted sequence. The images revealed dense thickening in the underlying cortex with a little cyst inside the lesion and $8 \mathrm{~mm}$ contrast-enhanced nodule. No significant mass effect was demonstrated.

A right pterional craniotomy, and anterior temporal lobectomy with amigdalo-hipocampoectomy was performed. Histopathology confirmed the diagnosis of meningioangiomatosis, showing ensheathment of the capillaries by fibroblasts and meningothelial cells.

The patient has remained free of seizures since surgery, suffered only a few episodes of aura the first months after surgery. She was without antiepileptic treatment since surgery.

\section{Discussion}

\section{Clinical presentation}

It usually affects children and young adults. Early onset of symptoms would suggest that the lesions are congenital or could arise as a fault of development ${ }^{12}$.

The lesion according to some authors ${ }^{25}$ has no sex predilection, whereas others ${ }^{28}$ favour a slight male predominance, unlike this article where all of the cases were females.

It may occur sporadically or in association with Neurofibromatosis type $2^{13}$. Most often the lesions are single clinically symptomatic when sporadic, but multiple asymptomatic lesions are seen in NF, possibly exclusively in $\mathrm{NF}^{2}$. Sporadic MA is four times more common than $\mathrm{MA}$ with $\mathrm{NF}^{6}$. MA associated to NF is found at early age than sporadic $\mathrm{MA}^{7}$.

Stemmer-Rachamimov et al. ${ }^{23}$, in an attempt to determine whether sporadic cases of MA were associated with somatic or germline alterations of the NF2 gene, screened the NF2 gene, they found that somatic mutations of the NF2 gene do not play a major role in sporadic MA.

The commonest presentation is progressive difficulty in controlling partial seizures, and seizures were the exclusive clinical problem in almost $85 \%$ of cases $^{5,29}$.

Scalp electroencephalography data revealed 2 patterns of epileptiform discharges. One resembled a focal lesion whose epileptogenicity is produced by adjacent cortex. A second pattern shows an epileptiform discharge that is similar to that of cortical dysplasia in which the lesion itself produces spikes ${ }^{16,28}$.

MA is most commonly located in cerebral cortex 
$(>80 \%)$ and structural lesions in these locations have been associated with a lowered seizure threshold ${ }^{10}$.

In patients with sporadic MA, the temporal lobe (33\%) is the most common location followed by the frontal lobe $(25 \%)$. In patients with MA associated with NF, the frontal lobe is the most common location for MA $(35 \%)^{16}$. interestingly, of the reported cases more than $80 \%$ are located in the right hemisphere ${ }^{21}$.

Other authors described unusual localizations such as the third ventricle, pulvinar-cerebral peduncle, corpus callosum, trigeminal ganglion, the brain stem, and the cerebellum ${ }^{16,17,28}$.

\section{Imaging}

The radiographic findings of MA may show a variety of features. The commonest finding on computerised tomography (CT) scan is usually iso- to slightly hyperintense that show variable amount of calcification with little or no contrast enhancement but low-density lesions and normal CT images have also been reported ${ }^{11,22,27}$.

MRI are confined to the cortex and consist of iso or hypointensity on T1- weighter images and heterogeneous cortical mass surrounded by an area of increased intensity on T2- weighter images, probably due to oedema or gliosis $^{6,18,25}$.

The presence of calcification on $\mathrm{CT}$ and a low signal intensity rim on T2-weighter MRI images are the most helpful features that suggest the diagnosis of MA.

However, MA may mimic other pathological processes on MRI, including meningioma, acute hemorrhage, calcifies arteriovenous malformation, and encephalomalacia $^{16,18}$.

In view of the wide spectrum of findings, presurgical diagnosis remains difficult because diagnostic tools lack specificity $^{8}$.

\section{Differential diagnosis}

The differential diagnosis should be made with others cortical tumours such as oligodendroglioma, ganglioglioma, dysembryoplastic neuroepithelial tumour (DNET), metastasis, meningioma and granulomatous meningitis.

Indeed MA have been associated with other lesions, including meningiomas ${ }^{2,5,11,15,29}$ vascular malformation ${ }^{8}$, oligodendroglioma ${ }^{14}$, astrocytoma, ependymoma, and primitive neuroectodermal tumor ${ }^{9}$, schwannoma ${ }^{8}$ and encephalocele.

Meningioma associated with MA, is the most frequent combination and a rare condition mimicking invasive meningioma both pathologically and radiologically ${ }^{15,29}$.

The most important differential diagnosis of menin- gioma with MA is because the prognosis and evolution of these 2 entities is entirely different ${ }^{24}$. Moreover, the MA can simulate an invasive meningioma because infiltration of the cortex by the proliferating of vascular cells, especially if associated with marked cellularity and reactive gliosis, may be erroneously interpreted as tumor invasion by those who are not familiar with this condition ${ }^{1,29}$.

Traditionally, determination of malignant meningioma is based on features such as brain invasion and/or histological anaplasia ${ }^{3}$. Brain invasion alone is no longer a reliable criterion of malignancy or predictor of bad prognosis ${ }^{19}$.

A correct diagnosis avoids unnecessary postoperative radiation or additional treatment ${ }^{13}$. Unless the pathologist is familiar with these pathological features of MA, these features may lead to an erroneous diagnosis.

\section{Surgery, pathological findings and outcome}

At surgery, the tumour appeared to involve a widened gyrus and was fibrous in appearance. The lesions are usually firm and well demarcated from the surrounding cerebral tissue. All of the tumours were confined to the cortex, with variable involvement of the overlying leptomeninges.

Although all cases of MA share unifying features, there are different degrees of histological presentation with cases predominantly cellular and others more fibrous and calcified $^{24}$. This could be due to different stages in the evolution of the lesion, with predominant fibrous lesions resulting from the evolution of the lesions predominantly cellular.

Microscopically irregularly branched blood vessels ${ }^{4}$, were unsheathed by spindle-shaped meningothelial cells and fibroblast cells had an onion-peel appearance ${ }^{12}$, extending into the gray matter from the meningeal surface.

Cortical neurons were entrapped within the lesion and rare neurofibrillary tangles were identified ${ }^{30}$. In some regions, numerous calcifications, including psammoma bodies, were present.

The lesion can extend into the perivascular space but spares the white matter ${ }^{8}$. No pleomorphism, mitoses, necrosis, or cortical invasions are associated with $\mathrm{it}^{6,20,28}$.

Immunohistochemistry has limited diagnostic value as staining patterns vary between cases ${ }^{12}$. Only viementin, as a non-specific marker of the mesenchymal cell was consistently positive ${ }^{27}$. Nonetheless, inmmunohistochemistry may aid in the differentiation and exclusion of other disorders such as meningioma and schwannoma, because the latter shares common histological features with MA.

The seizure-free rates after lesionectomy are variably and may afford improvement in between $43-68 \%$ of the cases, but almost $70-80 \%$ of the patients continued to required antiepileptic drugs 8 .

Its accurate diagnosis is important because total surgical removal is the treatment of choice, and after total excision; 
the lesion does not regrow ${ }^{3,20,25}$.

\section{Conclusion}

MA is a slow-growing lesion and we advocate early surgery, because is a surgically correctable cause of seizures. It is always benign without malignant potential characterized by proliferation of capillary-sized vessels, meningothelial cells, and fibroblasts within the cortex of the brain. Recognition of these lesion is vital, to avoid further aggressive treatment due to erroneous interpretation as aggressive meningioma.

\section{References}

1. Bassoe, P., Nuzum, F.: Report of a case of central and peripheral neurofibromatosis. J Nerv Ment Dis 1915; 42: 785796.

2. Blumenthal, D., Berho, M., Bloomfield, S., Schochet, S., Kaufman, H.: Childhood meningioma associated with meningioangiomatosis. J Neurosurg 1993; 78: 287-289.

3. Burger, P.C., Scheithauer, B.W.: Diagnosis and management of common intracranial tumors of childhood. Brain tumours in children: principles of diagnosis and treatment (The International Review of Child Neurology) Eds. ME Chohen, PK Duffner. New York: Raven Press, 1994: 347362.

4. Deb, P., Gupta, A., Sharma, M., Gaikwad, S., Singh, V., Sarkar, C.: Meningioangiomatosis with meningioma: an uncommon association of a rare entity-report of a case and review of the literature. Childs Nerv Syst 2005; 22: 78-83.

5. Giangaspero, F., Guidicci, A., Lenz, F.A., Mastronardi, L., Burger, P.C.: Meningioma with menngioangiomatosis: a condition mimicking invasive meningiomas in children and young adults: report of two cases and review of the literature. Am J Surg Pathol 1999; 23: 872-875.

6. Gómez-Anson, B., Muñoz, A., Blasco, A., et al. Meningioangiomatosis: advanced Imaging and pathological study of two cases. Neuroradiology 1995; 37: 120-123.

7. Harada, K., Inagawa, T., Nagasako, R.: A case of meningioangiomatosis without Von Recklinghausen disease. Report of a case and review of 13 cases. Childs Nerv Syst 1994; 10: 126-130.

8. Jallo, G., Kothbauer, K., Mehta, V., Abbott, R., Epstein, F.: Meningioangiomatosis without neurofibromatosis: a clinical analysis. J Neurosurg (Pediatrics) 2005; 103: 329-324.

9. Jay, V., Edwards, V., Varela-Stavrinou, M., Rutka, J.: Unique intracerebral tumor of a case wiyh features of astrocitoma, ependymoma, and PNET. Ultrastruct Pathol 1997; 21: 57-71.

10. Jay, G.W., Leestma, JE.: Sudden death in epilepsy. A comprehensive review of the literature and proposed mechanisms. Acta Neurol Scand (Suppl.) 1981; 82: 1-66.

11. Kim, N.R., Choe, G., Shin, S.H., Wang, K.C., Choe, B.K., Choi, K.S., Chi, J.G..: Childhood meningiomas associated with meningiomatosis: report of five cases and literature review. Neuropathol Appl Neurobiol 2002; 28: 48-56.

12. Kim, Y.W., Choi, W.S., Lee, J., Yang, M.H.: Meningioangiomatosis. A case report. J Korean Medical Science 1993; 8: 308-311.

13. Koutsopoulos A, Yannopoulos A, Stathopoulos E, et al.: Meningioangiomatosis with predominanthy cellular pattern. Case Report. Neuropathology 2003; 23: 141-145.

14. Lopez, J., Ereno, C., Oleaga, L., Areitio, E.: Meningioangiomatosis and oligodendroglioma in 15-year-old bpy. Arch Pathol Lab Med. 1996; 120: 587-590.

15. Mut, M., Soylemezoglu, F., Firat, M.M., Palaglu, S.: Intraparenchymal meningioma originating from underliyng meningioangimatosis. Case report and review of the literature. J Neurosurg 2000; 92: 706-710.

16. Omeis, I., Hillard, V., Braun, A., Benszil, D., Murali, R., Harter, D.: Meningioangiomatosis associated with neurofibromatosis: report of 2 cases in a single family and review of the literature. Surg. Neurol. 2006; 65: 595-603.

17. Park, M.S., Suh, D.C., Choi, W.S., Lee, S.Y., Kang, G.H.: Multifocal Meningoangiomatosis: A report of two cases. Am J Neuroradiol 1999; 20: 677-680.

18. Partingon, C.R., Graves, V.B., Megstrand, L.R.: Meningioangiomatosis. Am J Neuroradiol 1991; 12: 549-552.

19. Perry, A., Stafford, S.L., Scheithauer, B.W., Summan, V.J., Lohse, C.M.: Meningioma grading. An analysis of histologic parameters. Am J Surg Pathol 1997; 21: 1455-1465.

20. Prayson, R.A.: Meningioangiomatosis. A clinicopathologic study including MIBI immunoreactivity. Arch Pathol Lab Med 1995; 119: 1061-1064.

21. Rhodes, R.H., Davis, R.L.: An unusual fibro-osseous component in intracranial lesions. Hum Pathol 1978; 9: 309319.

22. Scroop, R., Voyvodic, F., Sage, MR.: Meningioangiomatosis. Australian Radiology 2000; 44: 460-463.

23. Stemmer-Rachamimov, A., Horgan, M., Taratuto, A., Muñoz, D.G., Smith T.W., Frost, M.P.: Meningioangiomatosis is associated with neurofibromatosis 2 but not with somatic alterations of the NF2gene. J Neuropathol Exp Neurol 1997; 56: 485-489.

24. Suarez-Gauthier, A., Gómez de la Bárcena, M.R., García-García, E., Hinojosa, J., Ricoy, J.R.: Meningioangiomatosis: report of two cases and literature review. Neurocirugía 2006; 17: 250-254.

25. Tacconi, L., Thom, M., Symon, L.: Cerebral meningioangiomatosis: case report. Surg Neurol 1997; 48: 255-260.

26. Takeshima, Y., Amatya, V.J., Nakayori, F., Nakano, T., Sugiyama, K., Inai, K.: Meningioangiomatosis occurring in a young male without neurofibromatosis: with special referente to its histogenesis and loss of heterozygosity in the NF2 gene region. Am J Surg Pathol 2002; 26: 125-129. 
27. Wang, Y., Gao, X., Yoa, Z., et al.: Histopathological study of five cases with sporadic meningioangiomatosis. Neuropathology 2006; 26: 249-256.

28. Wiebe, S., Munoz, D.G., Smith, S., Lee, D.H.: Meningioangiomatosis. A comprehensive analysis of clinical and laboratory features. Brain 1991; 122: 709-726.

29. Wilson, D., Dempsey, R.J., Clark, D.B.: Meningioma developing from underlying meningioangiomatosis. J Neuropathol Exp Neurol 1991; 50: 371-374.

30. Wixom, C., Chadwick, A., Krous, H.: Sudden, unexpected death associated with meningioangiomatosis: Case report. Pediatr Dev Pathol 2005; 8: 240-244.

31. Worster-Drought, C., Dickson, W., McMenemey, W.:
Multiple meningeal and perineural tumors with analogous changes in glia and ependyma (neurofibroblastomatosis). Brain 1937; 60: 85-117.

Arcos, A.; Serramito, R.; Santín, J.M.; Prieto, A.; Gelabert, M; Rodriguez-Osorio, X.; Reyes, R.: Meningioangiomatosis: clinical-radiological features and surgical outcome. Neurocirugía 2010; 21: 461-466.

Address: A. Arcos Algaba. Neurosurgical Service. Clinic Hospital of Santiago de Compostela. A Choupana. 15706 Santiago de Compostela (Spain).

socrandrea@hotmail.com 